\title{
Urokinase-dependent Adhesion Loss and Shape Change after Cyclic Adenosine Monophosphate Elevation in Cultured Rat Mesangial Cells
}

\author{
William F. Glass II, Robert A. Radnik, Jo Ann Garoni, and Jeffrey I. Kreisberg \\ Departments of Pathology and Medicine, The University of Texas, Health Science Center at San Antonio, San Antonio, Texas 78284
}

\begin{abstract}
Mesangial cells in culture change shape and become less adhesive in response to cAMP elevation (e.g., treatment with isoproterenol plus isobutylmethylxanthine (IM). Inhibitors of serine proteases inhibit cellular shape change in response to IM. To further examine the role of cell surface proteases in shape change, adhesion plaque proteins (i.e., preparations of ventral membranes and extracellular matrix) were separated in SDS-polyacrylamide gels containing gelatin with and without plasminogen. Four discrete zones of lysis were evident in plasminogen gels (indicative of activation of plasminogen) from control adhesion plaques: one inconspicuous zone with a $\boldsymbol{M}_{\mathbf{r}}$ $\sim 150 \mathrm{kD}$, another at $\sim 115 \mathrm{kD}$, and a doublet at $\sim 35-32$ kD. Another diffuse zone of lysis centered around $M_{\mathbf{r}} \sim 70 \mathrm{kD}$ and contained a defined band of $\sim 56 \mathrm{kD}$. Adhesion plaques contained most of the plasminogen activators (PA). 5 min after IM treatment, the $M_{\mathrm{r}} \sim 150$ - and $\sim 115-\mathrm{kD}$ PA were increased in activity. Vasopressin (VP), which prevented shape change and adhesion loss when added along with IM, inhibited the increase in these PA. Preincubation with monoclonal or polyclonal antibodies to urokinase-type plasminogen activator (uPA) totally inhibited the IM-inducible shape change and adhesion loss. Activation of plasminogen throughout the gels revealed multiple protease resistant bands that markedly increased with IM treatment (maximal at $45 \mathrm{~min}$ ). These may represent focal control mechanisms. uPA thus may mediate focal proteolysis, which results in shape change and decreased adhesion.
\end{abstract}

\section{Introduction}

Progressive sclerosis of the renal glomerulus occurs as a result of numerous, often dissimilar, disease processes including diabetes mellitus, hypertension, immune complex diseases, and toxic injury (1). The glomerulosclerotic processes observed are the results of accumulation of extracellular matrix proteins, generally within the mesangium. Cellular shape and function are regulated by interactions between these cells and the extracellular matrix. Therefore, investigation of the mechanism by

Part of this work was presented at the American Society of Nephrology meetings in Washington, DC, 13 December, 1987.

Address reprint requests to Dr. William F. Glass II, Department of Pathology, The University of Texas Health Science Center at San Antonio, 7703 Floyd Curl Drive, San Antonio, TX 78284.

Received for publication 12 January 1988 and in revised form 6 June 1988

J. Clin. Invest.

(C) The American Society for Clinical Investigation, Inc.

0021-9738/88/12/1992/09 \$2.00

Volume 82, December 1988, 1992-2000 which extracellular matrix controls shape will undoubtedly yield valuable insights into factors controlling glomerulosclerosis.

Glomerular mesangial cells are contractile cells of the glomerular mesangium that regulate the ultrafiltration coefficient, one component of the glomerular filtration rate, by their contractile activity. In primary culture or after early passages (i.e., <9) cultured mesangial cells isotonically contract (i.e., cell rounding) in response to angiotensin II and arginine vasopressin (VP) (2). This contractility is inhibited by agents that increase intracellular cAMP (e.g., isoproterenol and isobutylmethylxanthine [MIX] $]^{1}$ and chlorphenylthio cAMP and MIX [cAMP-MIX]) (3). After multiple passages in culture (i.e., $>9$ ), the cells become tightly adhered to the culture dish, display numerous bundles of stress fibers in the cytoplasm, and no longer respond to VP by isotonically contracting $(4,5)$. However, they show biochemical evidence of tension development in that myosin light chain phosphorylation increases (4, 6). Mesangial cells in prolonged culture respond to increases in intracellular cAMP by changing shape to a highly arborized configuration with long, thin cellular processes (7). At this time, stress fibers are fragmented, the myosin light chain is dephosphorylated (4), and the cells are less adhered to the plastic substratum (6). Interestingly, these changes are inhibited if VP is included with the cAMP-elevating agents.

The changes in cell shape, stress fiber morphology, and cell adhesion accompanying cAMP elevation in mesangial cells may be attributed to activation of cell surface proteases, as has been shown in other types of cells migrating through connective tissues (8). Cell migration through the extracellular matrix is believed to be a multistep process $(9,10)$ involving degradation of extracellular matrix components and cytoskeletal rearrangements to allow cellular translocation. Cell membraneassociated proteases have been shown to be involved with situations in which cell migration is necessary. For example, myoblast fusion (11), trophoblast implantation (12), neovascularization (13), and shape change and adhesion loss in transformed cells in culture (14-19).

Results of this study show that the cAMP-inducible shape change and adhesion loss are dependent on the activity of the urokinase-type plasminogen activator (uPA). Agents that affect the activity of this enzyme or its cellular inhibitors also modulate the extent of shape change and adhesion loss observed with cAMP-elevating agents. Understanding the mechanisms that may control normal glomerular mesangial cell adhesion is important if we are to explain the mechanisms that lead to abnormal mesangial cell function and matrix production in disease states.

1. Abbreviations used in this paper: cAMP-MIX, chlorphenylthio cAMP-MIX; IM, isoproterenol-MIX; MIX, isobutylmethylxanthine; PA, plasminogen activators; tPA, tissue-type plasminogen activator; uPA, urokinase-type plasminogen activator; VP, vasopressin. 


\section{Methods}

Isolation and culture of glomerular mesangial cells. Glomeruli were isolated from 200-g male Sprague-Dawley rats (Harlan Sprague-Dawley, Houston, TX) using a graded-sieve technique and were plated for culture in RPMI 1640 tissue culture medium with $20 \%$ FCS plus penicillin, streptomycin, and fungizone for explant growth of glomerular cells (6). Mesangial cells were isolated according to the differential growth capacities of glomerular epithelial and mesangial cells. With this method, the first cell type to emerge from the glomerulus was the glomerular epithelial cell; however, after $2 \mathrm{wk}$, mesangial cells appeared in the culture and proceeded to overgrow and obliterate the epithelial cells (6). On passaging with trypsin-versene $(0.25 \%$ trypsin and EDTA), glomeruli were filtered away, and homogeneous cultures of mesangial cells were obtained. Positive identification of this cell type was obtained by ultrastructural examination and ${ }^{125}$ I-angiotensin II binding capacity (2). Confluent cultures of mesangial cells were used between the 20th and 40th passages in culture.

Experimental protocols. Confluent cultures were rinsed three times with RPMI and treated for 5,20 , or $45 \mathrm{~min}$ with the following substances: $10^{-4} \mathrm{M}$ isoproterenol and $10^{-3} \mathrm{M}$ MIX; $10^{-3} \mathrm{M}$ CAMP-MIX; $10^{-7} \mathrm{M}$ isoproterenol-MIX with VP; and VP alone. For the inhibitor studies, cells were treated with the following protease inhibitors for 30 min before the addition of isoproterenol plus MIX (IM): $100 \mu \mathrm{g} / \mathrm{ml}$ soybean trypsin inhibitor, $100 \mathrm{U} / \mathrm{ml}$ aprotinin, $5 \times 10^{-4} \mathrm{M}$ leupeptin, $10^{-3} \mathrm{M}$ PMSF, and $2 \times 10^{-3} \mathrm{M}$ benzamidine. To study the effect of dexamethasone on plasminogen activators and inhibitors of plasminogen activators, cells were treated with $10^{-5} \mathrm{M}$ of Decadron phosphate (Merck Sharp and Dohme, West Point, PA) for $3 \mathrm{~d}$ before the experiment.

Preparation of adhesion plaques. After the experiments, adhesion plaques (composed of ventral membranes and extracellular matrix) were prepared using a modification of the $\mathrm{ZnCl}_{2}$ method described by Avner and Geiger (20). Briefly, cells were rinsed in $50 \mathrm{mM}$ Hepes

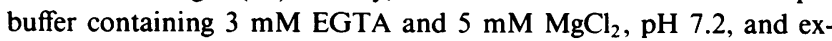
posed for 2 min to the above buffer containing $1 \mathrm{mM} \mathrm{ZnCl}$. After 2 $\mathrm{min}$, the adhesion plaques were prepared by shearing with vigorously pipetted buffer ( $25 \mathrm{mM}$ Hepes containing $3 \mathrm{mM} \mathrm{MgCl}, \mathrm{pH} 7.3$ ). Interference reflexion microscopy of these mesangial cell preparations confirmed the finding of Avner and Geiger that $\mathrm{ZnCl}_{2}$ preserves the close and focal contacts of ventral membranes with the underlying matrix. The adhesion plaques were dissolved in $2.5 \%$ SDS, $62.5 \mathrm{mM}$ Tris $\mathrm{HCl}$, pH 6.8 (electrophoresis sample buffer) for electrophoresis (21).

Preparation of cell fractions. Mesangial cells grown in $100-\mathrm{mm}$ culture dishes were incubated in RPMI 1640 with, and without, IM for $45 \mathrm{~min}$ as described above. Whole cells were prepared by extraction directly in sample buffer. Adhesion plaques were prepared as described above; however, the material removed by the shearing process was homogenized briefly with a glass-Teflon homogenizer and fractionated by differential centrifugation to yield a crude nuclear pellet $(10 \mathrm{~min}$ at $600 \mathrm{~g}$ ), remaining cellular membranes and organelles $(60 \mathrm{~min}$ at $100,000 \mathrm{~g}$ ) and cytosol (the final supernatant).

PAGE to detect protease activity and cellular inhibitors of proteases. Proteolytic activity was demonstrated as originally described by Heussen and Dowdle (22). 11\% SDS-polyacrylamide gels $(0.75 \mathrm{~mm}$ thick) were prepared with gelatin incorporated into the gel at a final concentration of $1 \mathrm{mg} / \mathrm{ml}$. To demonstrate plasminogen activators (PA), plasminogen ( 2 units per gel) were also added. Cell extracts were dissolved in electrophoresis sample buffer without reducing agent. Equal amounts of adhesion plaque protein were added. After electrophoresis, the gels were washed three times in $2.5 \%$ Triton X-100 for $1 \mathrm{~h}$ to remove the SDS and incubated overnight at $37^{\circ} \mathrm{C}$ in $\mathrm{HBSS}$ with $\mathrm{Ca}^{2+}$ and $\mathrm{Mg}^{2+}$ containing $10 \mathrm{mM}$ Hepes, $\mathrm{pH}$ 7.5. After incubation, the gels were stained with $0.1 \%$ amido black and destained in methanol/acetic acid/water (30:10:60). Protease activity was revealed by negative staining of transparent bands (i.e., zones of lysis). Changes in protease activity were quantitated by laser scanning densitometry using a laser densitometer (2202 Ultrascan; LKB Instruments, Houston, TX). Cellular PA inhibitors were detected in gels by washing the gel first in $2.5 \%$ Triton X-100 containing $50 \mathrm{IU}$ of urokinase in $100 \mathrm{ml}$ of washing solution. Gels were then incubated in HBSS as above.

Electrophoretic separation of adhesion plaque proteins. To visualize the major protein species present in adhesion plaque preparations, the samples in SDS were separated in linear pore gradient polyacrylamide gels ( $T=5-15 \%, C=2.65 \%)$ using the discontinuous buffer system of Laemmli (21). The SDS-polyacrylamide gels were then electrophoretically blotted onto nitrocellulose $(0.2-\mu \mathrm{m}$ pore; Hoefer Scientific Instruments, San Francisco, CA) overnight at $4^{\circ} \mathrm{C}$ in a transblot cell (Bio-Rad Laboratories, Richmond, CA) at $100 \mathrm{~V}$ (23). After transfer, the protein bands were stained according to the manufacturer's instructions with FerriDye (Janssen Life Sciences Products, Beerse, Belgium).

Effect of anti-uPA and anti-tissue plasminogen activator (anti-tPA) antibodies on shape change and cell adhesion. Cells were treated with either control IgG, a polyclonal anti-uPA $(500 \mu \mathrm{g} / \mathrm{ml}$ ) (Alpha Therapeutic Corp., Los Angeles, CA), a monoclonal anti-uPA $(10 \mu \mathrm{g} / \mathrm{ml})$ (Chemicon International, Los Angeles, CA), or a monoclonal anti-tPA $(10 \mu \mathrm{g} / \mathrm{ml})($ Pel-Freeze Biologicals, Brown Deer, WI) for $1 \mathrm{~h}$ before addition of isoproterenol $\left(10^{-4} \mathrm{M}\right)$-MIX $\left(10^{-3} \mathrm{M}\right)$.

Cells were exposed to isoproterenol-MIX in the continued presence of antibody and observed for shape change $45 \mathrm{~min}$ later. For the cell adhesion experiments, cells were treated as above with antibody for $1 \mathrm{~h}$ and exposed to RPMI alone or with isoproterenol-MIX. After $45 \mathrm{~min}$ the cells were washed twice in $\mathrm{Ca}^{2+}-\mathrm{Mg}^{2+}$-deficient $\mathrm{HBSS}$ and incubated in $\mathrm{Ca}^{2+}$ - and $\mathrm{Mg}^{2+}$-deficient HBSS containing the above agents and $0.02 \%$ trypsin for $15 \mathrm{~min}$ at $37^{\circ} \mathrm{C}(6)$. The supernatant was gently pipetted off for cell counting, and the remaining monolayer was treated with trypsin-versene to determine the percent of cells remaining after the first trypsin treatment.

\section{Results}

Previously we reported that mesangial cells develop numerous bundles of microfilaments called stress fibers and become tightly adhered to the plastic substratum after multiple passages in culture $(4,6)$. When these cells are treated with cAMP-elevating agents such as CAMP-MIX or IM, they change shape to an arborized configuration with long, thin cellular processes. In association with this shape change, stress fibers are fragmented, myosin light chain is dephosphorylated and the cells are much less adhered to the plastic substratum $(4,6)$. If the contractile agent VP is added along with the cAMP-elevating agents, the above changes are prevented. This effect of VP occurs despite cAMP levels being 15 -fold higher than control levels (control $=27.5 \pm 0.5 ; \mathrm{IM}=804 \pm 26.7$; IMVP $=412 \pm 7.8 \mathrm{pmol} / \mathrm{mg}$ protein) (24). Because activation of membrane-associated proteases has been associated with shape change and adhesion loss in other cultured cells (8), we examined whether such proteases were involved with shape change in mesangial cells.

Mesangial cells were preincubated with the following serine protease inhibitors for $30 \mathrm{~min}$ before the addition of IM: 100 $\mu \mathrm{g} / \mathrm{ml}$ soybean trypsin inhibitor, $100 \mathrm{U} / \mathrm{ml}$ aprotinin, $0.5 \mathrm{mM}$ leupeptin, $1 \mathrm{mM}$ PMSF, and $2 \mathrm{mM}$ benzamidine. Both PMSF and benzamidine significantly inhibited shape change induced by IM (Fig. 1). Whereas IM causes $100 \%$ of the cells to change shape, pretreatment with PMSF or benzamidine reduces the amount of cells changing shape to $\sim 25 \%$. The other inhibitors were without effect.

As we reported previously a decrease in focal and close contacts and loss of cell adhesion in mesangial cells treated 

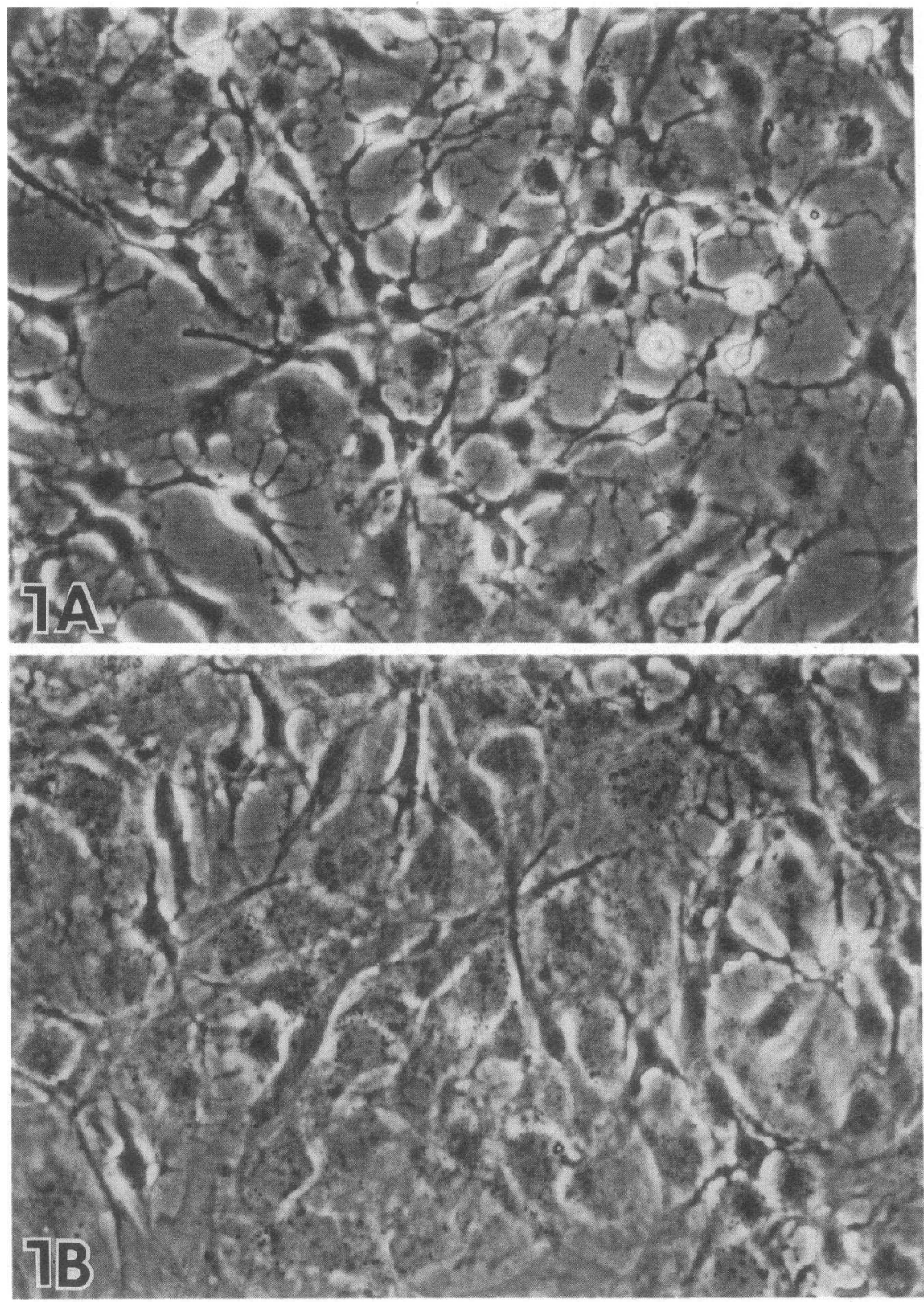

Figure 1. (A) Photograph of cultured mesangial cells treated with IM for $45 \mathrm{~min}$. Notice that the cells have changed shape. $(B)$ Mesangial cells treated with IM in the presence of 1 mM PMSF. Notice that the mesangial cells are greatly inhibited from changing shape. $\times 1,000$. with cAMP-elevating agents, (6), we expected that if proteases were involved with shape change, they might be exerting their effects at these focal contact sites. Therefore, we prepared cell fractions composed predominantly of ventral membranes and extracellular matrix (referred to in this manuscript as adhesion plaques). Adhesion plaques from control cells in multiple experiments $(>100)$ represent $\sim 10-12 \%$ of total cellular protein. After treatment with IM, only $\sim 3-5 \%$ of the total protein is recovered in the adhesion plaques. With quantitative changes of this magnitude, one might expect major qualitative changes in protein species. However, when equal amounts of AP protein are electrophoretically separated, transferred to nitrocellulose, and stained with FerriDye (a highly sensitive method of protein staining) no major differences are observed between control, IM-treated, and VP-treated adhesion plaque proteins (Fig. 2). Zymographic analysis of adhesion plaques prepared from control cells, cells treated with cAMP-elevating agents, VP or both in gelatin gels containing plasminogen (P- gel) revealed the presence of four distinct zones of lysis indicative of plasminogen activation (Fig. 3); (a) a faint zone with $M_{\mathrm{r}}$ $\sim 150 \mathrm{kD} ;(b)$ a more intense zone with $M_{\mathrm{r}} 115 \mathrm{kD}$; and $(c)$ two zones with $M_{\mathrm{r}} 35-32 \mathrm{kD}$. A broad, diffuse zone that centered around $M_{\mathrm{r}} 70 \mathrm{kD}$ was also observed. Within this broad, diffuse zone were several faint, discrete bands, the species with the greatest mobility having an $M_{\mathrm{r}}$ of $56 \mathrm{kD}$. Treatment of cells with cAMP-elevating agents, which results in shape change, resulted in an increase in activity of PA. In particular, PA with apparent $M_{\mathrm{r}} 150$ and $115 \mathrm{kD}$ consistently showed elevations (> 100 experiments) in activities as evidenced by an increase in the zones of lysis (Fig. 3). Laser scanning densitometry revealed, in six different experiments, a 1.6-4-fold increase in the intensity of the $150-\mathrm{kD}$ band and the $115-\mathrm{kD}$ band increased from 1.5-13-fold after IM treatment. Occasionally small changes were noted in other bands; however, these were inconsistent. The gelatin degrading activity of each protease was maximum at neutral $\mathrm{pH}(\mathrm{pH} 7.0-8.0)$. These PA were 


\section{ADHESION PLAQUE PROTEINS \\ 5-15\% GRADIENT PAGE}

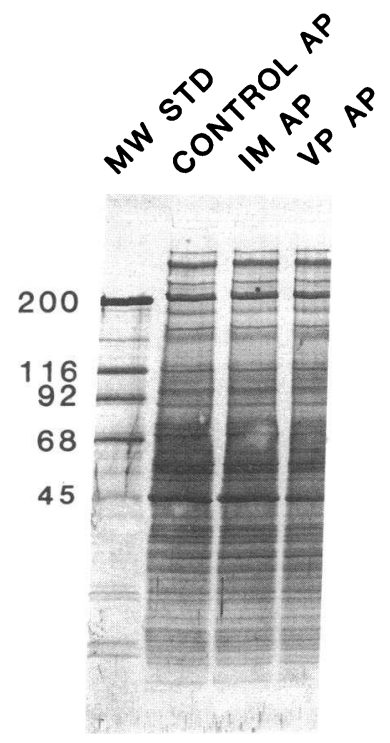

Figure 2. AP proteins separated by SDS-PAGE. Mesangial cells were treated with RPMI 1640 alone (control), IM, and VP. AP proteins (10 $\mu \mathrm{g}$ each) were separated on 5-15\% polyacrylamide gels, blotted electrophoretically onto nitrocellulose, and stained with FerriDye.

increased by $5 \mathrm{~min}$ and maximum activity (i.e., zone lysis) was reached after $20 \mathrm{~min}$ and maintained through $45 \mathrm{~min}$ of IM treatment. Maximum shape change occurred after $45 \mathrm{~min}$ of IM. Inclusion of VP in the IM incubation medium inhibited shape change and returned PA to control levels (Fig. 3). VP treatment alone, which has no discernible effect on mesangial cell morphology by phase contrast microscopy, did not appear to affect the activity of PA. Adhesion plaque preparations separated on gels containing only gelatin did not show any evidence of protease activity (Fig. 4).

The subcellular distributions of the PA were examined by differential centrifugation of the material sheared during preparation of adhesion plaques. The whole cell preparation, total particulate fraction containing cellular membranes, attached cytoskeleton, and organelles (minus ventral membranes and nuclei), the cytosolic fraction, and adhesion plaques (AP) were examined for expression of PA. Fig. 5 shows that the activity of the $115-\mathrm{kD}$ protease in the whole cell treated with IM is essentially unchanged over control whole cells. In the original gel, trace quantities of the $150-\mathrm{kD}$ PA are detectable in whole cell preparations. PA of all mobilities were enriched in the adhesion plaques compared to the other fractions. The $150-\mathrm{kD}$ PA was confined almost exclusively to the adhesion plaques and the cytosolic fraction exhibited no PA.

Although these results suggest that a PA is involved in mechanisms of shape change/adhesion loss, they do not allow definitive identification of the plasminogen activator type. To directly determine whether the mechanism involved uPA or tPA, cells were pretreated for $60 \mathrm{~min}$ at $37^{\circ} \mathrm{C}$ with antibodies against these enzymes followed by IM treatment for $45 \mathrm{~min}$. Both polyclonal antibodies (data not shown) and monoclonal antibodies to uPA totally inhibited the shape change, whereas normal rabbit IgG and monoclonal antibody to tPA were without effect (Fig. 6). MAb to uPA, but not tPA, totally prevented the loss of adhesion by both an assay based on cellular detachment (Table I) and as assessed by interference reflexion microscopy (data not shown). In fact, both methods of assessing adhesion indicated that pretreatment with MAb to urokinase not only prevented adhesion loss with IM but actually increased cellular adhesion above control (Table I).

To further ascertain which bands represented uPA, samples of rat urine proteins were evaluated by zymography (Fig.

\title{
ADHESION PLAQUES
}

\author{
P-GEL PAGE
}
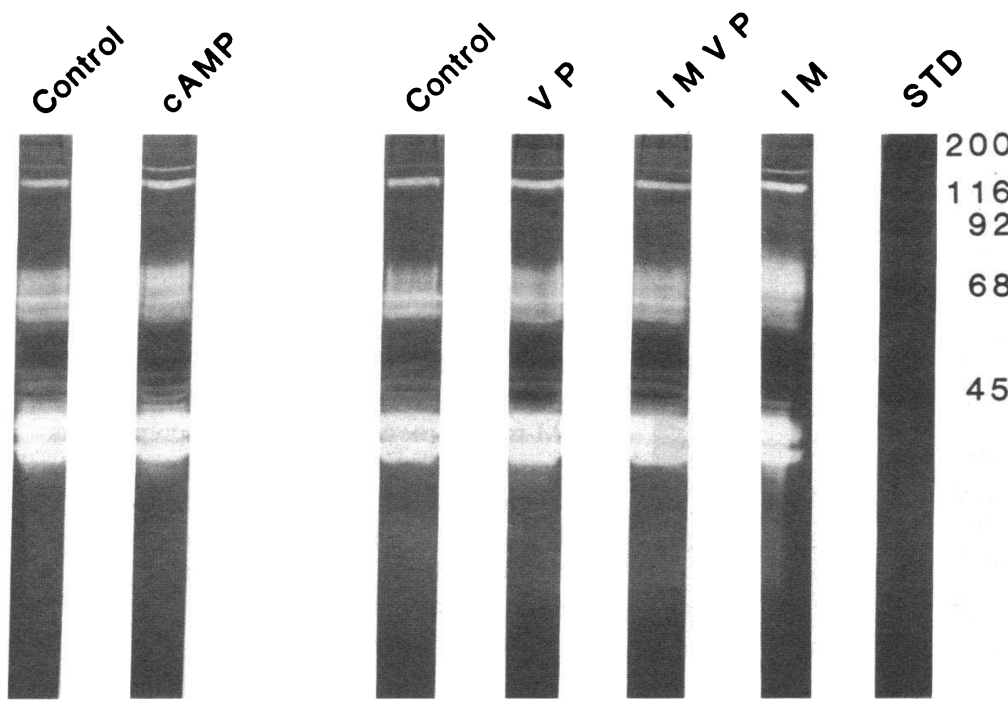

Figure 3. Photograph of P-Gel PAGE to demonstrate PA in adhesion plaques from mesangial cells treated with chlorphenylthio cAMP ( $1 \mathrm{mM}, \mathrm{cAMP})$, IM with and without VP, and VP alone. PA with apparent molecular weights of 150 and $115 \mathrm{kD}$ are increased in activity with cAMP and IM. Laser scans of zones of intensity of lysis revealed with cAMP treatment that the 150 - and $115-\mathrm{kD}$ bands were increased $\sim 50 \%$. The isoproterenol-MIX induced a fourfold increase in the 150-kD PA and a 50\% increase in zone intensity of the 115-kD PA. VP addition returned activity to control levels. $5 \mu \mathrm{g}$ of protein were added to each lane. 


\title{
ADHESION PLAQUES
}

\author{
GEL PAGE
}
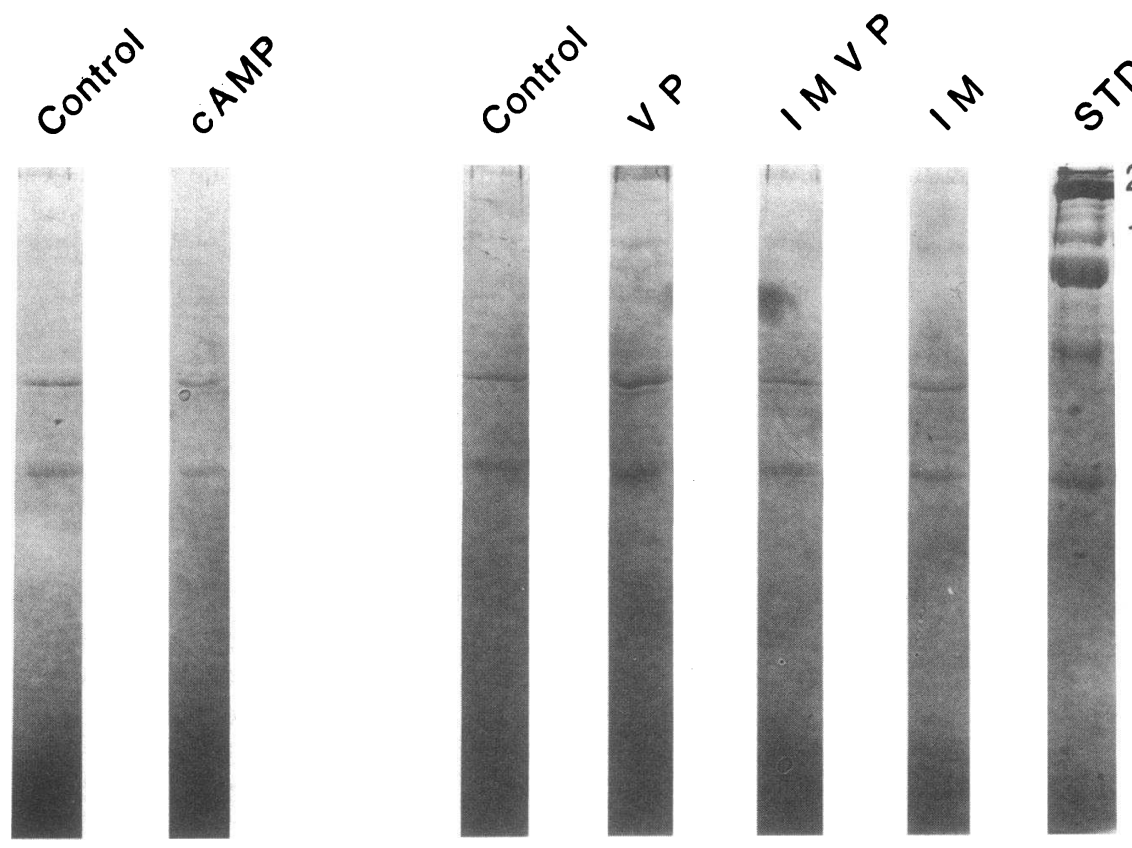

116

92

68

45

Figure 4. Photograph of a gel-PAGE (no plasminogen) to demonstrate gelatinases. As is evident, adhesion plaques from mesangial cells do not contain active gelatinases. $5 \mu \mathrm{g}$ of protein was added to each lane.

\section{CELL FRACTIONS}

\section{P-GEL PAGE}
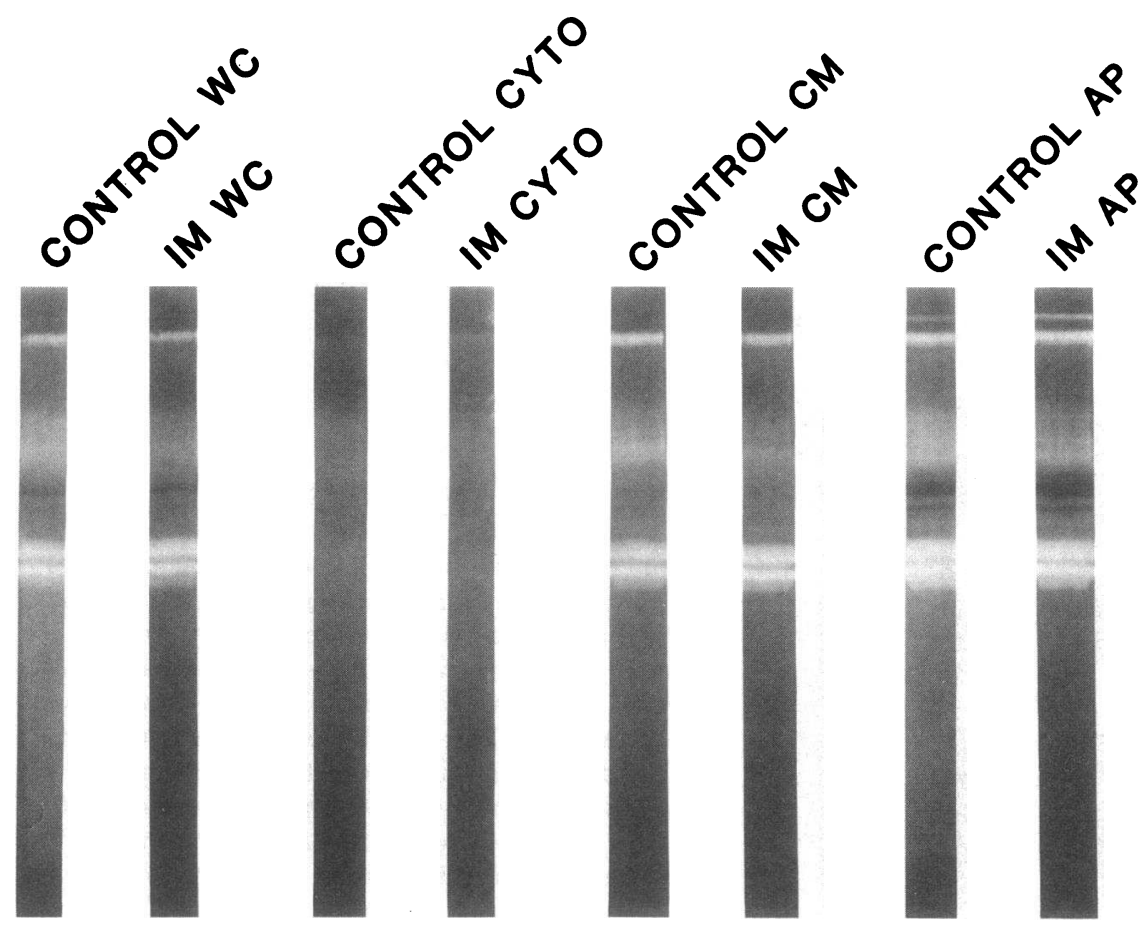

Figure 5. PA present in cellular fractions isolated by differential centrifugation. Proteins ( 5 $\mu \mathrm{g}$ each) in control (RPMI 1640 alone) and IM-treated mesangial cells were prepared as described in Methods. By laser scanning densitometry, the 150-kD PA was increased 2.5fold in IM AP vs. control AP. (Whole cells, WC; cytoplasm, cyto; cellular membranes minus ventral membranes and nuclei, $\mathrm{CM}$; adhesion plaques, AP.) 

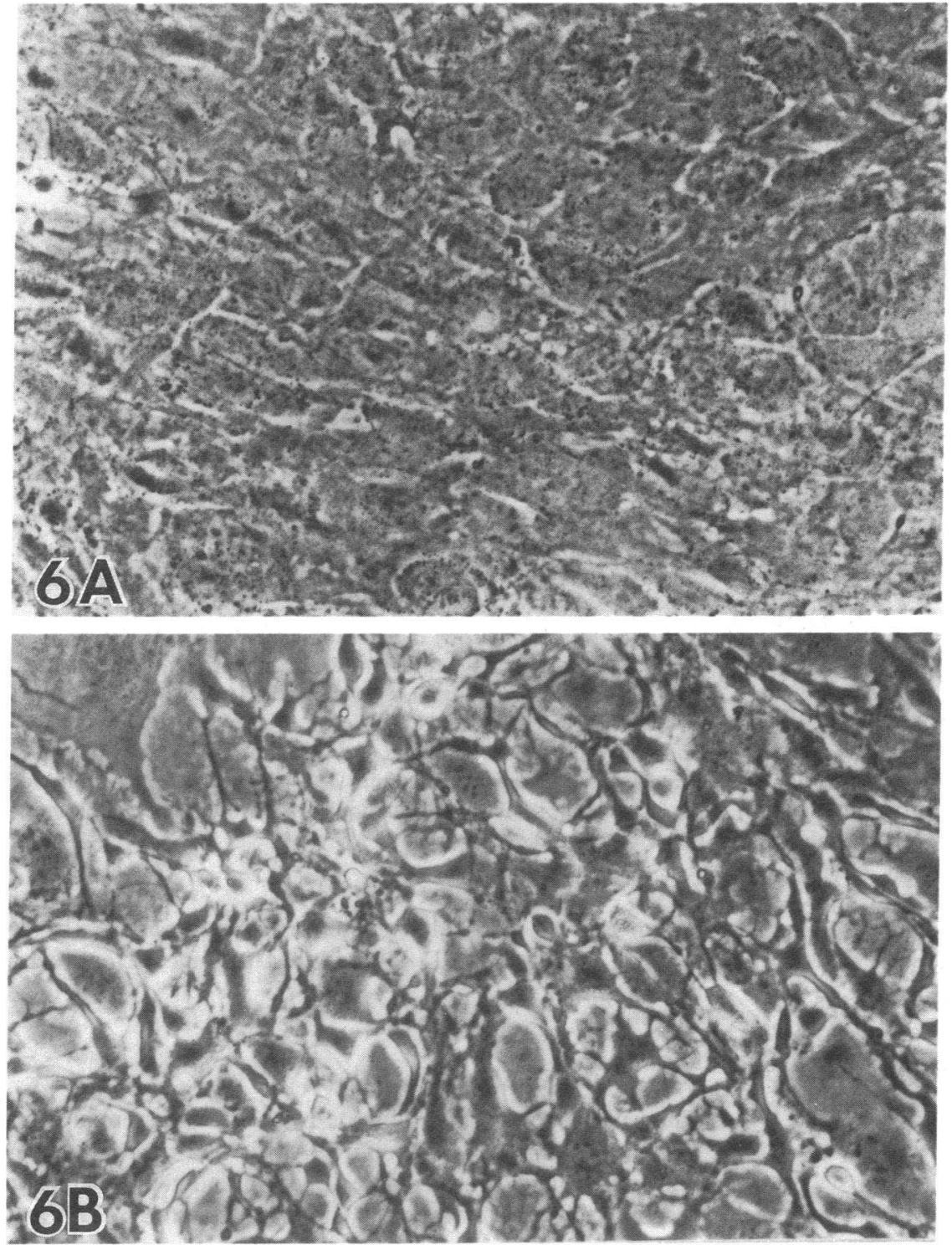

Figure 6. The effect of MAb against uPA on IM-induced shape change in cultured mesangial cells. Cells were treated with either $(A)$ MAb against UPA $(10 \mu \mathrm{g} / \mathrm{ml})$ or $(B)$ MAb against tPA $(10 \mu \mathrm{g} / \mathrm{ml})$ for $1 \mathrm{~h}$ before addition of isoproterenol $\left(10^{-4} \mathrm{M}\right)$-MIX $\left(10^{-3} \mathrm{M}\right)$ and observed for shape change at $45 \mathrm{~min}$. Notice that the anti-uPA-treated cells were prevented from changing shape. $\times 1,000$.
7). Dependent on the amount of urine applied to the gel, bands comigrating with each of the major species present in adhesion plaques were identifiable, including bands at $M_{\mathrm{r}} 115,56$, and 35-32 kD.

Because of trace amounts of active plasmin in the gels, endogenous inhibitors of plasmin were also often observed.

Table I. Effect of MAb against $U P A$ and $t P A$ on the Adhesion Loss Caused by Isoproterenol/MIX

\begin{tabular}{llc}
\hline \multicolumn{1}{c}{ Condition } & \multicolumn{1}{c}{ MAb } & \% detached $( \pm \mathrm{SE})$ \\
\hline Control & None & $10.4(0.9)$ \\
Isoproterenol/MIX & None & $53.8(3.2)$ \\
Isoproterenol/MIX & Anti-uPA & $1.6(0.15)$ \\
Isoproterenol/MIX & Anti-tPA & $45.5(2.9)$ \\
\hline
\end{tabular}

$P<0.05$ for control vs. all conditions.

$P<0.05$ for isoproterenol/MIX vs. isoproterenol/MIX plus anti-uPA.

\section{RAT URINE UROKINASE}

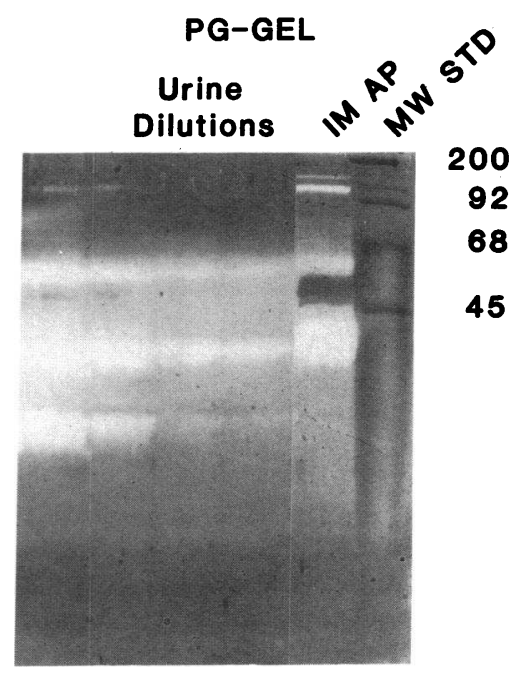

Figure 7. Photograph of P-Gel PAGE showing PA present in IM-adhesion plaques $(3 \mu \mathrm{g})$ and various amounts of rat urine $\left(2,2 \times 10^{-1}, 2\right.$ $\times 10^{-2}$, or $\left.2 \times 10^{-3} \mu \mathrm{l}\right)$. 
Inspection of Figs. 3 and 5 shows that inhibitors migrating in the 43-50-kD range reside exclusively in the AP and that these increase in intensity with IM treatment (see below for more information). Because no major changes are observed between control and IM-adhesion plaque proteins (Fig. 2), changes seen in dark bands are due to inhibition of gelatin lysis.

To assess whether IM treatment causes the expression of endogenous plasmin or urokinase inhibitors, plasminogen gels were incubated with urokinase to activate plasminogen throughout the gel. Protease-resistant bands appeared at apparent $M_{\mathrm{r}} 49$ and $44 \mathrm{kD}$ with IM treatment (Fig. 8). These inhibitors may be involved with controlling proteolysis at the sites of cell contact.

Dexamethasone has been reported to increase the levels of plasminogen activator inhibitors in cells and to decrease the synthesis of uPA (see Discussion). We tested the ability of dexamethasone-treated mesangial cells to change shape in response to IM, and found it to be appreciably decreased (data not shown). We examined adhesion plaque preparations from dexamethasone treated cells by zymography (Fig. 9). Dexamethasone-treated cells exhibited decreased plasminogen-dependent lysis by PA migrating at $M_{\mathrm{r}} 115$ and $150 \mathrm{kD}$. Again, because of trace quantities of plasmin, inhibitors of gelatinolysis are observed. These are notably increased in the dexamethasone-treated cells. Preliminary results, using a chromogenic assay (Chromozym U; Boehringer-Mannheim, Biochemicals, Indianapolis, IN) and purified high molecular weight uPA (Calbiochem-Behring Corp., La Jolla, CA), confirm the zymographically observed increase within adhesion plaques of activities inhibitory to uPA after dexamethasone treatment. Fig. 8 also shows zymographic analysis of conditioned media from the above experiments, in which cells were treated with dexamethasone and/or IM. The changes in PA and inhibitor, where present, paralleled those observed in ad-

\section{ADHESION PLAQUES}

\section{P-GEL PAGE UROKINASE}

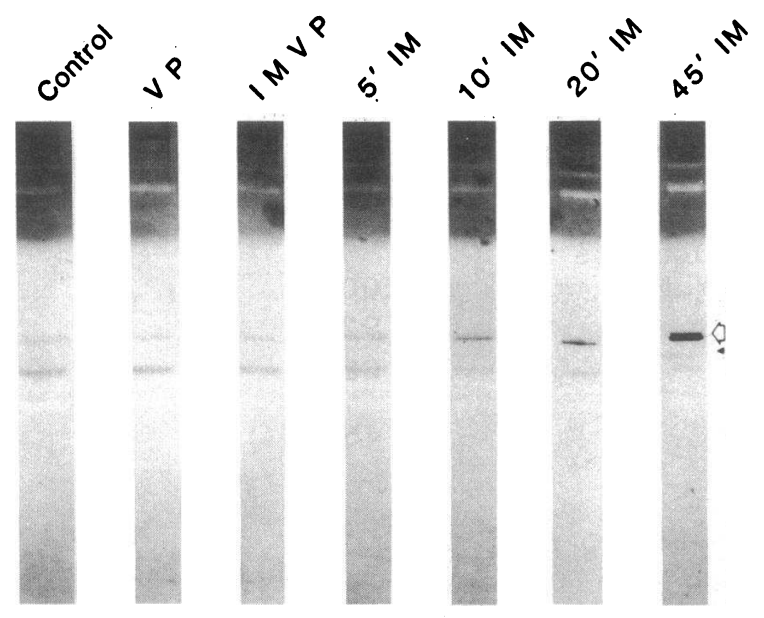

Figure 8. Photograph of P-gel PAGE treated with urokinase (50 IU for $6 \mathrm{~h}$ ) to reveal endogenous protease inhibitors. Notice that an inhibitor at $49 \mathrm{kD}$ increases progressively with time (open arrowhead), whereas an inhibitor at $\mathbf{4 4} \mathbf{~ k D}$ appears at $\mathbf{4 5} \mathrm{min}$ of (IM) treatment (closed arrowhead). $5 \mu \mathrm{g}$ of protein were added to each lane.

\section{DEXAMETHASONE TREATMENT}

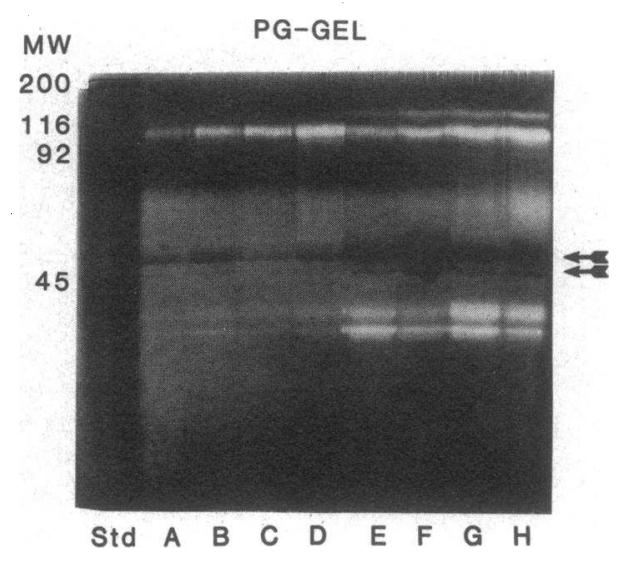

Figure 9. Photograph of P-Gel PAGE showing the effect of dexamethasone $\left(10^{-5} \mathrm{M}\right.$ for $\left.3 \mathrm{~d}\right)$ on PA present in conditioned media and adhesion plaques. Equal amounts of protein ( $3 \mu \mathrm{g}$ each) were separated by P-Gel PAGE. Lanes $A-D$ show PA released into culture media (RPMI 1640) during the 45-min incubation period of the shape change. Lanes $E-H$ represent PA present in adhesion plaques from the same experiment. Samples from cells treated with dexamethasone are demonstrated in lanes $A, B, E$, and $F$, whereas those from untreated cells are in lanes $C, D, G$, and $H$. Samples from IMtreated cells were separated in lanes $B, D, F$, and $H$. Arrows point to the locations of inhibitors of gelatinolysis by traces of active plasmin present in the gel.

hesion plaques. Particularly noteworthy is the increase in activity of the $M_{\mathrm{r}} 115 \mathrm{kD}$ PA with IM and its decrease with dexamethasone.

\section{Discussion}

This study shows that urokinase performs an essential function, inhibitable by a specific MAb, in the mechanism by which mesangial cells decrease adhesion and change shape in response to cAMP elevation. Zymographic analysis of PA separated in SDS indicated that mesangial cell fractions composed of ventral membranes and extracellular matrix (i.e., adhesion plaques) contain PA with many different apparent molecular weights.

Several of the bands present in adhesion plaques $\left(M_{\mathrm{r}} 115\right.$, 56 , and 35-32 kD) comigrate with PA species present in rat urine. The molecular mass generally reported for high molecular weight uPA is $M_{\mathrm{r}} \sim 50 \mathrm{kD}(25-27)$. The low molecular weight uPA is $M_{\mathrm{r}} \sim 30 \mathrm{kD}(25-27)$, whereas that of tPA is $\sim 70 \mathrm{kD}(25,27)$. Our slight discrepancy for the size of the high molecular weight form of uPA probably arises from variations caused by electrophoresis of unreduced proteins and possibly from interactions with the gelatin substrate present in the gel. Although we are unaware of any other reports of the very high molecular weight species, that is the $M_{\mathrm{r}} 115 \mathrm{kD}$, in rat urine, other studies have generally used indirect zymography (in which an indicator gel is placed against the SDS gel) to reveal PA. We have found indirect zymography to be many orders of magnitude less sensitive than the direct zymographic method of Heussen and Dowdle (22). For example, one study using indirect zymography required $7 \mu \mathrm{l}$ of rat urine to observe zones of lysis corresponding to the high molecular weight $\left(M_{\mathrm{r}}\right.$ $48,000 \mathrm{kD}$ ) form of uPA (28). In our study using direct zymo- 
graphy, we observed corresponding species (migrating at 56 $\mathrm{kD})$ with $2 \times 10^{-3} \mu \mathrm{l}$ of rat urine.

Dexamethasone has been consistently reported to suppress uPA activity in a variety of cultured cells and tissues, whereas the response of tPA activity has been more variable (see $\mathrm{K}$. Dano et al. [reference 25] for review). Further, dexamethasone has also been reported to increase the activities of inhibitors of PA (29-31). Our observations in cellular adhesion plaques and in conditioned media are consistent with observations generally made for UPA and its cellular inhibitors. The major classes of cellular inhibitors of plasminogen activators include plasminogen activator inhibitor types I and II and the protease nexins $(26,27)$. Only the latter, protease nexin, is reported to also inhibit plasmin (32). Our results suggest that the bands observed in zymograms containing traces of plasmin represent protease nexins. Studies are in progress to further characterize which inhibitors are present in mesangial cell cultures.

The very high $M_{\mathrm{r}}$ bands, 115 and $150 \mathrm{kD}$, most likely represent complexes of UPA with ligands such as the inhibitors noted above or other uPA molecules. SDS-resistant interactions of PA with each of the above ligands have been described. Stable, apparently covalent interactions with inhibitors are most commonly described (33-38). One plausible explanation is that the PA inhibitor complexes represent stable enzymesubstrate intermediates; thus, the high molecular weight species occur when the complexes are slowly hydrolyzed during the course of the zymographic incubation, generating active PA and cleaved inhibitor. Similar explanations have been proposed $(35,37)$. The broad diffuse area of gelatinolysis observed centering around $M_{\mathrm{r}} 70 \mathrm{kD}$ may represent PA-inhibitor complexes that dissociated during the course of electrophoresis. A similar phenomenon has been described (33).

Dimeric and trimeric complexes of uPA would result in bands with the approximate molecular weights we describe. Disulfide-linked oligomers of uPA with $M_{\mathrm{r}}>1$ million have been described in a lung cancer cell line (39). The possibility exists that formation of such high molecular weight oligomers might be favored by aggregation of receptor bound uPA.

The shape change and adhesion loss occurring in cultured mesangial cells in response to cAMP elevation is prevented by the serine protease inhibitors PMSF and benzamidine, but not by plasmin inhibitors aprotinin and soybean trypsin inhibitor. Since specific immunoglobulin is capable of blocking the shape change, inaccessibility of the much smaller inhibitor molecules is an unlikely explanation for a lack of effect. Thus, a plasmin-independent mechanism may be involved.

Recently, it has been demonstrated that normal and transformed cells contain cell surface proteases that may be involved with focal digestion of extracellular matrix, resulting in shape change and adhesion loss (14-19). Quigley and associates have demonstrated the presence of PA on the surface of normal and RSV-transformed chick embryo fibroblasts (17, 18). The shape change and adhesion loss induced by phorbol ester treatment of transformed chick fibroblasts was due to the PA on the cell surface. Serine protease inhibitors but not inhibitors of plasmin inhibited this shape change. These data, in combination with the observation that an MAb to urokinase activator similarly inhibited shape change, led the authors to suggest a direct catalytic involvement of UPA in matrix digestion (19). In support of this, Gold et al. recently showed that urokinase had the ability to digest the matrix component fibronectin from its dimeric form to yield near monomeric fragments (40). Pollanen et al. localized uPA by immunocytochemistry and immunoelectron microscopy to cell-to-cell and cell-to-substratum contacts in normal fibroblasts and HT-1080 sarcoma cells (33). In other studies, Chen and associates demonstrated fibronectin-degrading proteases on the cell surfaces of transformed fibroblasts that appear to function in the local degradation of fibronectin. Fibronectin degradation was sensitive to metalloprotease and serine protease inhibitors (14-16). Thus, this focal localization of PA at the sites of cell contact is poised for focal proteolysis.

In conclusion, mesangial cells after multiple passages in culture respond to elevations in intracellular cAMP by a urokinase-dependent mechanism resulting in stress fiber fragmentation, shape change, and adhesion loss, presumably through digestion of cell adhesion contacts. Another role of urokinase may be plasmin-dependent activation of latent collagenase. Lovett et al. demonstrated that mesangial cells in culture secrete a metalloendopeptidase that specifically cleaves type IV collagen of the glomerular basement membrane (41). This enzyme, along with urokinase, may be of critical importance in the regulation of mesangial matrix material. An imbalance between synthesis and degradation of matrix material may lead to accumulation of matrix material in disease states. Understanding the molecular determinants between cells and the extracellular matrix is crucial if we are to understand normal cell function and differentiation. Once these mechanisms are clarified, the changes that occur to cells in disease states will be easier to explain.

\section{Acknowledgments}

We wish to thank Sharon Cloer for typing the manuscript.

The work was supported by National Institutes of Health grants DK-29787, DK-37139, and DK-17387, and a grant from the National Kidney Foundation.

\section{References}

1. Adler, S., L. J. Striker, G. E. Striker, D. T. Perkinson, J. Hibbert, and W. G. Couser. 1986. Studies of progressive glomerular sclerosis in the rat. Am. J. Pathol. 123:553-562.

2. Ausiello, D. A., J. I. Kreisberg, C. Roy, and M. J. Karnovsky. 1980. Contraction of cultured rat glomerular cells of apparent mesangial origin after stimulation with angiotensin II and arginine vasopressin. J. Clin. Invest. 65:754-760.

3. Venkatachalam, M. A., and J. I. Kreisberg. 1985. Agonist-induced isotonic contraction of cultured mesangial cells after multiple passage. Am. J. Physiol. 249:(Cell Physiol. 18)C48-C53.

4. Kreisberg, J. I., M. A. Venkatachalam, R. A. Radnik, and P. Y. Patel. 1985. Role of myosin light chain phosphorylation and microtubules in stress fiber morphology in cultured mesangial cells. Am. J. Physiol. 249:(Renal Fluid Electrolyte Physiol. 18)F227-F235.

5. Kreisberg, J. I., M. A. Venkatachalam, and D. A. Troyer, 1985. Contractile properties of cultured glomerular mesangial cells. Am. J. Physiol. 249:(Renal Fluid Electrolyte Physiol. 18)F457-F463.

6. Kreisberg, J. I., and M. A. Venkatachalam. 1986. Vasoactive agents affect mesangial cell adhesion. Am. J. Physiol. (Cell Physiol. 20)C505-C511.

7. Kreisberg, J. I., M. A. Venkatachalam, and P. Y. Patel. 1984. cAMP-associated shape change in mesangial cells and its reversal by $\mathrm{PGE}_{2}$. Kidney Int. 25:874-879.

8. Trinkaus, J. P. 1984. Cells into organs. In The Forces That Shape the Embryo. 2nd ed. Prentice-Hall, Englewood Cliffs, NJ. 543. 
9. Liotta, L. A., C. N. Rao, and S. H. Barsky. 1983. Tumor invasion and the extracellular matrix. Lab. Invest. 49:636-649.

10. Ruoslahti, E. 1984. Fibronectin in cell adhesion and invasion. Cancer Metastasis Rev. 3:45-51.

11. Couch, C. B., and W. J. Strittmatter. 1983. Rat myoblast fusion requires metalloendoprotease activity. Cell. 32:257-265.

12. Glass, R. H., J. Aggeler, A. Spindle, R. A. Pederson, and Z. Werb. 1983. Degradation of extracellular matrix by mouse trophoblast outgrowths: a model for implantation. J. Cell Biol. 96:1108-1116.

13. Kalebic, T., S. Garbisa, B. Glaser, and L. A. Liotta. 1983. Basement membrane collagen: degradation by migrating endothelial cells. Science (Wash. DC). 282-283.

14. Chen, W. T., K. Olden, B. A. Bernard, and F. F. Chu. 1984. Expression of transformation-associated protease(s) that degrade fibronectin at cell contact sites. J. Cell Biol. 98:1546-1555.

15. Chen, W. T., J. M. Chen, S. J. Parsons, and J. T. Parsons. 1985. Local degradation of fibronectin at sites of expression of the transforming gene product pp 60 Src. Nature (Lond.). 316:156-158.

16. Chen, J. M., and W. T. Chen. 1987. Fibronectin-degrading proteases from the membranes of transformed cells. Cell. 48:193-203.

17. Quigley, J. P. 1976. Association of a protease (plasminogen activator) with a specific membrane fraction isolated from transformed cells. J. Cell Biol. 71:472-486.

18. Quigley, J. P. 1979. Phorbol ester-induced morphological changes in transformed chick fibroblasts: evidence for direct catalytic involvement of plasminogen activator. Cell. 17:131-141.

19. Sullivan, L. M., and Quigley, J. P. 1986. Anti-catalytic monoclonal antibody to avian plasminogen activator: its effect on behavior of RSV-transformed chick fibroblasts. Cell. 45:905-915.

20. Avner, Z., and B. Geiger. 1981. Substrate-attached membranes of cultured cells. Isolation and characterization of ventral cell membranes and the associated cytoskeleton. J. Mol. Biol. 153:361-379.

21. Laemmli, U. K. 1970. Cleavage of structural proteins during the assembly of the head of bacteriophage $\mathrm{T}_{4}$. Nature (Lond.). 227:680-685.

22. Heussen, C., and Dowdle, E. B. 1980. Electrophoretic analysis of plasminogen activators in polyacrylamide gels containing sodium dodecyl sulfate and copolymerized substrates. Anal. Biochem. 102:196-202.

23. Towbin, H., T. Staehelin, and J. Gordon. 1979. Electrophoretic transfer of proteins from polyacrylamide gels to nitrocellulose sheets: procedure and some applications. Proc. Natl. Acad. Sci. USA. 76:4350-4354.

24. Kreisberg, J. I. 1988. The cell biology and biochemistry of glomerular mesangial cells. J. Miner. Electrolyte Metab. 14:167-175.

25. Dano, K., P. A. Andreasen, J. Grondahl-Hansen, P. Kristensen, L. S. Nielsen, and L. Skriver. 1985. Plasminogen activators, tissue degradation and cancer. Adv. Cancer Res. 44:139-266.

26. Blasi, F., J. D. Nassalli, and K. Dano. 1987. Urokinase-type plasminogen activator: proenzyme, receptor, and inhibitors. J. Cell Biol. 104:801-804.

27. Saksela, O. 1985. Plasminogen activation and regulation of pericellular proteolysis. Biochim. Biophys. Acta. 823:35-65.
28. Dano, K., L. S. Nielsen, V. Moller, and M. Engelhart. 1980. Inhibition of a plasminogen activator from oncogenic virus-transformed mouse cells by rabbit antibodies against the enzyme. Biochim. Biophys. Acta. 630:146-151.

29. Coleman, P. S., P. D. Patel, B. J. Cnikel, U. M. Rafferty, R. Szynycer-Laszuk, and T. D. Gelehrter. 1986. Characterization of the dexamethasone-induced inhibitor of plasminogen activator in HTC hepatoma cells. J. Biol. Chem. 261:4352-4357.

30. Crutchley, D. J., L. B. Conanar, and J. R. Maynard. 1981. Human fibroblasts produce inhibitor directed against plasminogen activator when treated with glucocorticoids. Ann. NY Acad. Sci. 370:609-616.

31. Andreasen, P. A., C. Pyke, A. Riccio, P. Kristensen, L. S. Nielsen, L. R. Lund, F. Blasi, and K. Dano. 1987. Plasminogen activator type 1 biosynthesis and mRNA level are increased by dexamethasone in human fibrosarcoma cells. Mol. Cell. Biol. 7:3021-3025.

32. Scott, R. W., B. L. Bergmann, A. Bajpai, R. T. Hersh, H. Rodiguez, B. N. Jones, C. Barreda, S. Watts, and J. B. Baker. 1985. Protease nexin. Properties and modified purification procedure. $J$. Biol. Chem. 260:7029-7034.

33. Pollanen, J., O. Saksela, E. M. Salonen, P. Anderson, L. Nielsen, K. Dano, and A. Vaheri. 1987. Distinct localizations of urokinase-type plasminogen activator and its type 1 inhibitor under cultured human fibroblasts and sarcoma cells. J. Cell Biol. 104:10851096.

34. Laiho, M., O. Saksela, and J. Keski-Oja. 1987. Transforming growth factor- $\beta$ induction of type-1 plasminogen activator inhibitor. Perinuclear depsition and sensitivity to exogenous urokinase. J. Biol. Chem. 262:17467-17474.

35. Nielsen, L. S., P. A. Andreasen, J. Grondahl-Hansen, L. Skriver, and K. Dano. 1986. Plasminogen activators catalyse conversion of inhibitor from fibrosarcoma cells to an inactive form with a lower apparent molecular mass. FEBS (Fed. Eur. Biochem. Soc.) Lett. 196:269-273.

36. Krnithof, E. K. D., J. D. Vassulli, W. D. Schleuning, R. J. Mattaliano, and F. Bachmann. 1986. Purification and characterization of a plasminogen activator inhibitor from the histiocytic lymphoma cell line U-937. J. Biol. Chem. 261:11207-11213.

37. Travis, J. and G. S. Salvesen. 1983. Human plasma proteinase inhibitors. Annu. Rev. Biochem. 52:655-709.

38. Knudsen, B. S., P. C. Harpel, and R. L. Nachman. 1987. Plasminogen activator inhibitor is associated with the extracellular matrix of cultured bovine smooth muscle cells. J. Clin. Invest. 80:1082-1089.

39. Harvey, S., J. Minowada, H. Takita, L. Kover, and G. Markus. 1982. Urokinase-like plasminogen activators of unusually high molecular weight secreted by a cell line derived from a human lung cancer case. J. Biol. Chem. 257:5645-5651.

40. Gold, L. I., R. Schwimmer, and J. P. Quigley. 1987. Human plasma fibronectin is a substrate for the plasminogen activator, human urokinase. J. Cell Biol. 105:216a. (Abstr.)

41. Lovett D. H., R. B. Sterzel, and J. L. Ryan. 1983. Neutral proteinase activity produced in vitro by cells of the glomerular mesangium. Kidney Int. 23:342-349. 